\title{
Applied Research
}

National Cancer Institute

\section{Source}

National Cancer Institute. Applied Research. NCI Thesaurus. Code C15715.

Research directed toward solving a specific problem. 